\title{
2-Hydroxy-5-methylbenzophenone oxime(HMBO) as an Analytical Reagent for Gravimetric Determination of $\mathrm{Cu}$ (II)
}

\author{
S. K. SHINGADIA and K. K. DESAI* \\ Department of Chemistry, \\ Veer Narmad South Gujarat University, \\ Surat- 395 007. Gujarat. India. \\ Tel. No. +91-261-2256012 Fax No. +91-261-2256012 \\ kdesaichem@rediffmail.com, tellent_shailesh@yahoo.com
}

Received 13 August 2006; Revised 11 September 2006; Accepted 15 October 2006

\begin{abstract}
HMBO) was developed as a new analytical reagent for the gravimetric determination of divalent copper ion. In $\mathrm{pH}$ rang of 3.0 to 6.0 , the reagent gives a buff colored precipitate with $\mathrm{Cu}(\mathrm{II})$. Job's method and mole ratio method revealed that the stoichiometry of the complex is 1:2 (metal: ligand). Beer's law is obeyed up to $61.25 \mathrm{ppm}$ of $\mathrm{Cu}(\mathrm{II})$. Molar absorptivity and Sandell's sensitivity at $400 \mathrm{~nm}$ were found to be $6.32 \times 10^{2} \mathrm{~L} \mathrm{~mol}^{-1} \mathrm{~cm}^{-1}$ and 0.359 $\mu \mathrm{g} / \mathrm{cm}^{2}$ respectively. The stability constant of $\mathrm{Cu}(\mathrm{II})-\mathrm{HMBO}$ complex is found to be $2.43 \times 10^{9}$. Gibb's free energy change for complex formation reaction was found to be $-12.88 \mathrm{Kcal} / \mathrm{mol}$. The reagent can be used for the analysis of brass and alloy.
\end{abstract}

Keywords: Oxime, Analytical reagent, 2-hydroxy-5-methyl benzophenone oxime, HMBO. 


\section{Introduction}

In the current scenario of analytical chemistry, many reagents are widely available. They include o-hydroxy ketoximes ${ }^{1-3}$, phenyl hydrazones, thiosemicarbazone ${ }^{4-6}$, chalcone oximes ${ }^{7}$ etc. These are generally used for spectrophotometric and gravimetric determination of transition metal ions. In this work, we report the use of 2-hydroxy-5-methylbenzophenone oxime (HMBO) as a gravimetric reagent for $\mathrm{Cu}(\mathrm{II})$. Spectrophotometric methods have been used to confirm the stoichiometry of complex and to determine the stability constants of the complex. The reagent is used to determine copper in brass and alloy.

\section{Experimental}

\section{Instruments}

Schimadzu UV- visible spectrophotometer (160-A) was used for all absorbance and $\mathrm{pH}$ of solutions were measured on Elico-pH meter (LI-10T) and buffer solution of required $\mathrm{pH}$ were obtained using (sodium acetate-acetic acid) and (hydrochloric acid-sodium acetate) buffers of suitable concentration.

\section{Synthesis of 2-Hydroxy-5-methylbenzophenone oxime (HMBO)}

p-Cresyl benzoate was prepared from p-cresol, water and benzoyl chloride in presence of $\mathrm{NaOH}$. 2-hydroxy-5-methylbenzophenone was prepared from p-cresyl benzoate using Fries reaction in presence of anhydrous $\mathrm{AlCl}_{3}$. 2-Hydroxy-5-methylbenzophenone oxime was prepared from the ketone by sodium acetate method. It was crystallized from ethanol; colourless needles (m.p. $110 \pm 2{ }^{\circ} \mathrm{C}$ ) were obtained. The reagent is soluble in solvents like ethanol, carbon tetrachloride, acetone, DMF etc.

The elemental analysis of the reagent was found to be:

\begin{tabular}{ccc}
\hline Elements & Calculated & Found \\
\hline Carbon & 77.66 & 77.56 \\
Hydrogen & 5.77 & 5.80 \\
Nitrogen & 12.44 & 12.42 \\
\hline
\end{tabular}

\section{Stock solution}

A $0.05 \mathrm{M}$ stock solution of $\mathrm{Cu}(\mathrm{II})$ was prepared by dissolving requisite amount of anhydrous $\mathrm{CuSO}_{4} .5 \mathrm{H}_{2} \mathrm{O}$ in double distilled water, little free acid were added in it and was used after standardization with EDTA. Solutions of required concentrations were prepared by diluting above stock solution. Solution of the reagent HMBO $(0.05 \mathrm{M})$ was prepared by dissolving oxime in $70 \%$ aqueous ethanol.

\section{Gravimetric procedure}

A $0.05 \mathrm{M}$ solution of the reagent in $70 \%$ aqueous ethanol was used. Copper sulphate solution $(0.05 \mathrm{M}, 10.0 \mathrm{~mL})$ taken in a clean beaker was diluted to about $100.0 \mathrm{~mL}$ with distilled water and $\mathrm{pH}$ of the solution was adjusted to 3.0-6.0 with suitable buffer. The solution was warmed at $60{ }^{\circ} \mathrm{C}$ and small excess of reagent solution was added $(0.05 \mathrm{M}, 22.0$ $\mathrm{mL}$ ). A buff precipitate obtained was digested on water bath for 1 hour at $60{ }^{\circ} \mathrm{C}$. The precipitate was filtered through a previously weighed sintered glass crucible $\left(\mathrm{G}_{4}\right)$. The precipitate was washed with hot water followed by $70 \%$ aqueous ethanol to remove excess of the reagent which might have precipitated on dilution. The chelate was dried to constant weigh at $110-115{ }^{\circ} \mathrm{C}$ in hot air oven, cooled and weighed. 


\section{Gravimetric determination of $\mathrm{Cu}(\mathrm{II})$}

To establish the applicability of the reagent for gravimetric estimation of $\mathrm{Cu}(\mathrm{II})$, the metal ion was determinate in the $\mathrm{pH}$ range 3.0-6.0. The maximum error being $\pm 1 \%$. Estimation were done at $\mathrm{pH} 5.0$ using different aliquots of $\mathrm{Cu}(\mathrm{II})$. In all cases the error in $\mathrm{Cu}(\mathrm{II})$ content did not exceed $\pm 0.84 \%$ (Table -1 ).

Table - 1. Result of gravimetric estimation of copper (II) at $\mathrm{pH} 5.0$; $\mathrm{Cu}(\mathrm{II})-\mathrm{HMBO}$

\begin{tabular}{ccccc}
\hline $\mathrm{Cu}(\mathrm{II})$ taken & $\mathrm{Cu}(\mathrm{II})$ complex & $\mathrm{Cu}(\mathrm{II})$ found & \multicolumn{2}{c}{ Error } \\
\cline { 3 - 5 } $\mathrm{mg}$ & $\mathrm{g}$ & $\mathrm{mg}$ & $\mathrm{mg}$ & $\%$ \\
\hline 15.89 & 0.1289 & 15.88 & -0.01 & +0.06 \\
31.77 & 0.2601 & 32.04 & +0.27 & +0.84 \\
47.66 & 0.3874 & 47.72 & +0.06 & +0.13 \\
63.56 & 0.5180 & 63.81 & +0.25 & +0.39 \\
\hline
\end{tabular}

Interference

To study the effect of foreign ions on gravimetric determination of $\mathrm{Cu}(\mathrm{II}), 8-10 \mathrm{mg}$ of various cations were added to solution containing $31.77 \mathrm{mg} \mathrm{Cu}(\mathrm{II})$ at $\mathrm{pH} 5.0$ and gravimetric estimations were done. It was observed that $\mathrm{Mg}(\mathrm{II}), \mathrm{Ca}(\mathrm{II}), \mathrm{Mn}(\mathrm{II}), \mathrm{Ni}(\mathrm{II}), \mathrm{Sr}(\mathrm{II}), \mathrm{Zn}$ (II), $\mathrm{Ba}(\mathrm{II}), \mathrm{Cd}(\mathrm{II})$ and $\mathrm{Al}(\mathrm{III})$ do not interfere at this $\mathrm{pH}$ but $\mathrm{Pd}(\mathrm{II}), \mathrm{Co}(\mathrm{II})$ and $\mathrm{Fe}(\mathrm{III})$ interfere seriously. Many common anions like chlorides, bromide, iodide, nitrate, nitrite, sulphate were not found to interfere.

\section{Spectrophotometric study of Cu(II)-HMBO complex}

For taking the absorbance spectra $5.0 \mathrm{mg}$ chelate was dissolved in $25.0 \mathrm{~mL}$ chloroform and the absorbance was measured in the range of $350-800 \mathrm{~nm}$. It was observed that absorbance of the solution increased continuously towards the shorter wavelength. The absorbance spectrum showed a shoulder at $400 \mathrm{~nm}$ and hence all measurement was carried out at $400 \mathrm{~nm}$.

The $\mathrm{Cu}(\mathrm{II})-\mathrm{HMBO}$ complex is insoluble in methanol and ethanol. It is soluble in solvent like chloroform, MIBK, 1:4 dioxane etc. Hence the complex was extracted in chloroform. For spectrophotometric studies varying amount of $\mathrm{Cu}$ (II) solution was taken and $\mathrm{pH}$ was adjusted to 5.0 with (sodium acetate + acetic acid) buffer and $\mathrm{HMBO}$ solution was extracted with three 5.0 $\mathrm{mL}$ portion of chloroform and the volume of chloroform extract was made up to $25.0 \mathrm{~mL}$ the absorbance of chloroform extract was measured against reagent blank.

Validity of Beer's law

The $\mathrm{Cu}$ (II)-HMBO complex in chloroform obeys law up to $61.25 \mathrm{ppm}$ of $\mathrm{Cu}(\mathrm{II})$. Beyond this concentration the absorbance plot showed deviation from linearity (Figure 1). Standard graph thus obtained may be used for the determination of copper in an unknown solution using HMBO. Molar absorptivity calculated from Beer's law plot was found to be $6.32 \mathrm{x}$ $10^{2}$ lit. $\mathrm{mol}^{-1} \mathrm{~cm}^{-1}$ for $\mathrm{Cu}(\mathrm{II})-\mathrm{HMBO}$ complex at $400 \mathrm{~nm}$ and Sandell's sensitivity was calculated and found to be $0.359 \mu \mathrm{g} / \mathrm{cm}^{2}$ of $\mathrm{Cu}$ (II) at $400 \mathrm{~nm}$. 


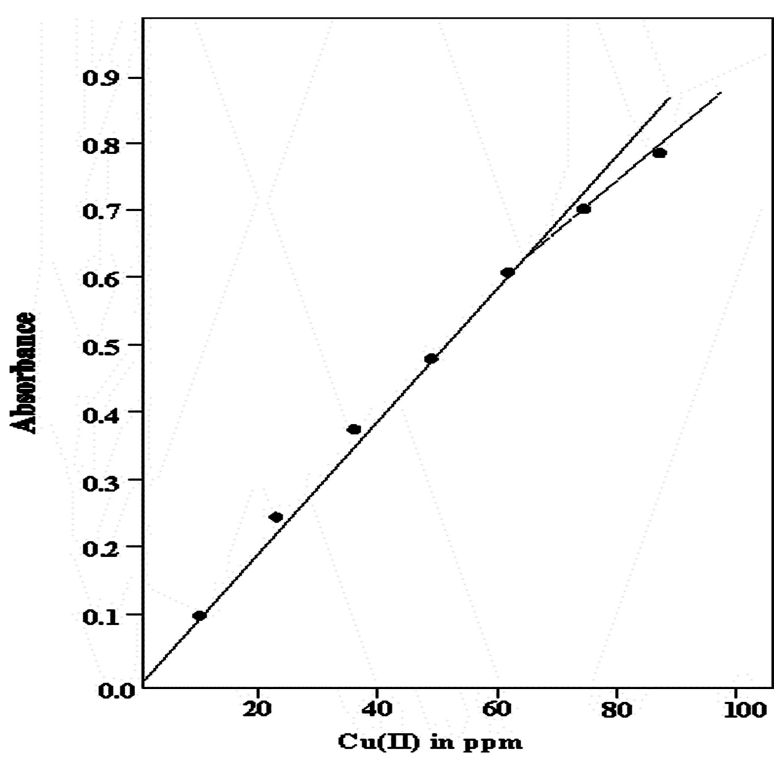

Stoichiometry of complex

Figure 1.

The stoichiometry of $\mathrm{Cu}(\mathrm{II})-\mathrm{HMBO}$ complex was determined by (1) Job's method of continuous variation ${ }^{8}$, and (2) Yoe and Jone's mole ratio method ${ }^{9}$ (Figure 2-3). Both the methods gave the metal: ligand ratio of the complex 1:2. This is in agreement with the stoichiometry found from gravimetry. From this data the structure of complex can be written as follows:

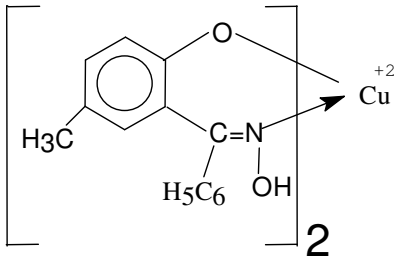

Stability constants of the complex

The stability constants of the complex were calculated using the formula:

$$
\mathrm{K}_{\mathrm{s}}=[1-\alpha] /\left[4 \alpha^{3} \mathrm{C}^{2}\right]
$$

Where, $\alpha=\left(\mathrm{E}_{\mathrm{m}}-\mathrm{E}_{\mathrm{s}}\right) /\left(\mathrm{E}_{\mathrm{m}}\right)$

$\mathrm{E}_{\mathrm{m}}=$ maximum absorbance obtained at the intersect of the two lines.

$\mathrm{E}_{\mathrm{s}}=$ absorbance at the stoichiometric ratio of the metal to reagent in complex

The average stability constant found from two methods is $2.43 \times 10^{9}$ from Ks value.

Gibb's free energy change for complex formation reaction was calculated and its value was

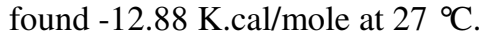


Job's method for Cu(II)-HMBO complex.

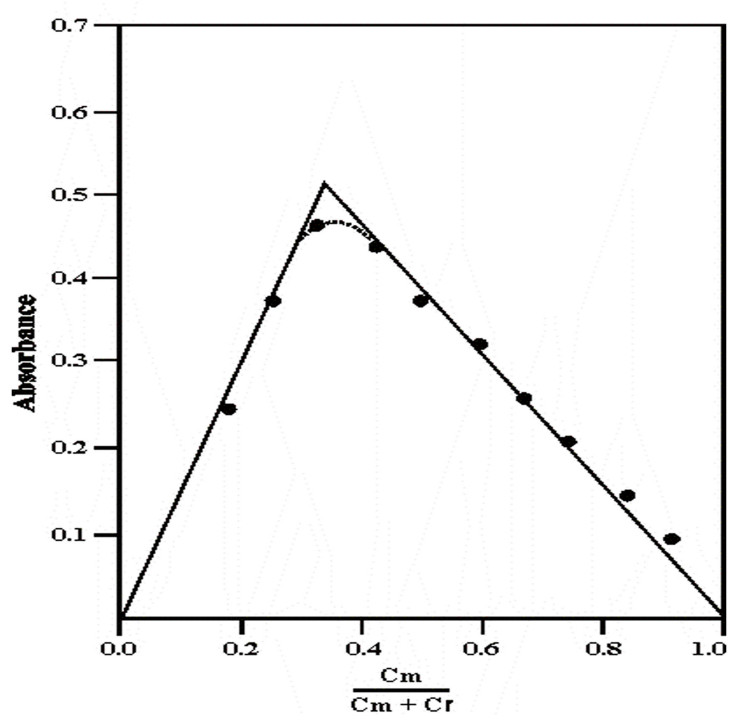

Figure -2. Job's method for $\mathrm{Cu}(\mathrm{II})-\mathrm{HMBO}$ complex

Plots of Job's method of continuous variation for determination of M:L ratio $0.005 \mathrm{M} \mathrm{Cu}(\mathrm{II}), 0.005 \mathrm{M}$ HMBO;

$\mathrm{pH}=5.0 ; \lambda=400 \mathrm{~nm}$.

Mole-ratio method for Cu(ii)-HimBo complex.

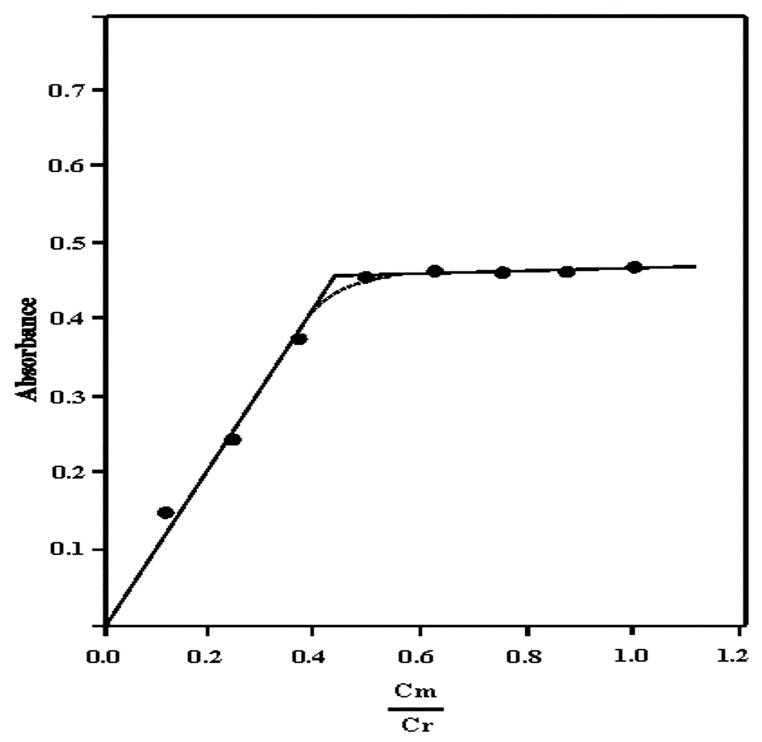

Figure -3. Mole-ratio method for $\mathrm{Cu}(\mathrm{II})-\mathrm{HMBO}$ complex Plots of Yoe and Jone's method for determination of M:L ratio $0.005 \mathrm{M} \mathrm{Cu}(\mathrm{II}), 0.005 \mathrm{M} \mathrm{HMBO} ; \mathrm{pH}=5.0 ; \lambda=400 \mathrm{~nm}$. 


\section{Determination of Copper in Brass}

Exactly sample of brass $(0.5589 \mathrm{~g})$ was dissolved in $50 \% \mathrm{HNO}_{3}$ by heating for 30 minutes. The excess of nitric acid was boiled off and the solution was diluted to $100.0 \mathrm{~mL}$ with distilled water. The aliquot $10.0 \mathrm{~mL}$ was taken and $\mathrm{Cu}(\mathrm{II})$ was determined gravimetrically at pH 5.0 as described earlier. $\mathrm{Zn}(\mathrm{II})$ and other trace metal did not interfere at this $\mathrm{pH}$. The experiment was repeated three times. $\mathrm{Cu} \%$, found: 71.01 ; reported: 70.50 .

Gravimetric estimation of $\mathrm{Cu}(\mathrm{II})$ in german-silver using $\mathrm{HMBO}$

Exactly weighed quantity of german-silver $(0.9338 \mathrm{~g})$ was transferred to a $250.0 \mathrm{ml}$ beaker. $50.0 \mathrm{~mL} \mathrm{1:1} \mathrm{nitric} \mathrm{acid} \mathrm{was} \mathrm{put} \mathrm{in} \mathrm{it.} \mathrm{The} \mathrm{solution} \mathrm{was} \mathrm{heated} \mathrm{to} \mathrm{dissolve} \mathrm{the} \mathrm{alloy.} \mathrm{Excess}$ nitric acid was boiled off and the solution was diluted to $100.0 \mathrm{ml}$ with distilled water.

$10.0 \mathrm{~mL}$ aliquot was taken and $\mathrm{Cu}(\mathrm{II})$ was determined a $\mathrm{pH} 5.0$ as described earlier. $\mathrm{Ni}(\mathrm{II})$ and other trace metal did not interfere at this $\mathrm{pH}$. The experiment was repeated three times. $\mathrm{Cu} \%$, found: 56.44 ; reported: 56.00 .

\section{Conclusion}

2-Hydroxy-5-methylbenzophenone oxime (HMBO) is suitable reagent for spectrophoto metric determination of $\mathrm{Cu}(\mathrm{II})$. Many anions and cations were not found to interfere.

\section{Acknowledgement}

The authors are thankful to Prof. Dr. K. R. Desai, Head of the Chemistry Department, Veer Narmad South Gujarat University, Surat for the facilities and cooperation in the work.

\section{Reference}

1. Raghava R, Naidu K S, Santhalaxmi and Krishanan V S, J Chem. Soc., 1985, 62, 79.

2. Patel N B and Desai K K, Asian J. Chem., 1999, 3, 1080,.

3. Purohit K and Desai K K, Acta Ciencia Indica, 2005, 4, 329.

4. Desai M J and Desai K K, Asian J. Chem., 1999, 4, 1313.

5. Cano Pavon J M, Bendito D P and Pino F, An. Quim., 1971, 67, 299.

6. Gandhi H C and Desai K K, Asian J. Chem., 2003, 15, 549.

7. Desai M J, Desai P G and Mehta A G, Asian J Chem, 1999, 77, 519.

8. Job P, Ann., 1928, 9, 113; 1936, 6, 97; Compt. Rend., 1925, 180, 928.

9. Yoe J H and Jones A L, Ind. Eng. Chem. Anal. Ed., 1944, 16, 111. 


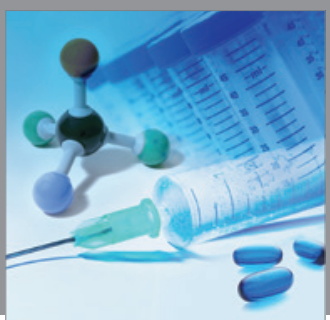

International Journal of

Medicinal Chemistry

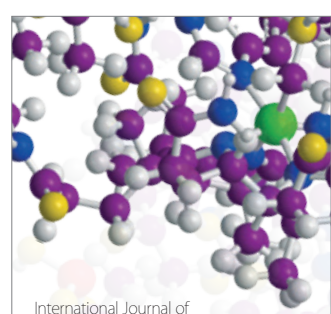

Carbohydrate Chemistry

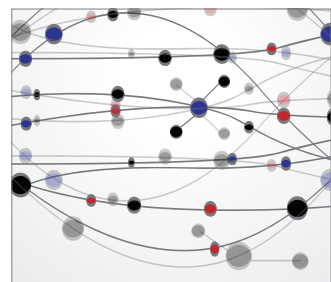

The Scientific World Journal
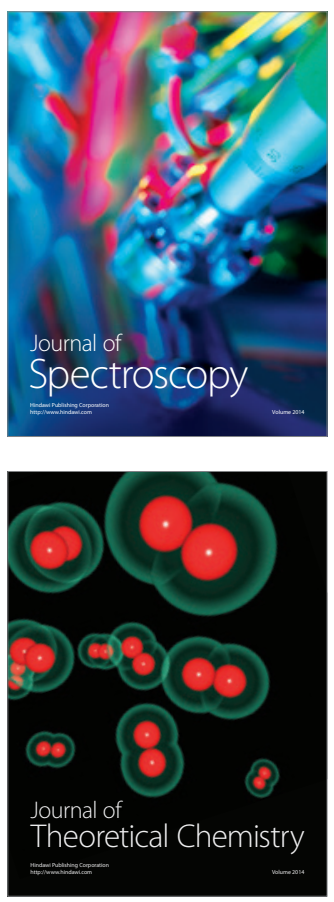
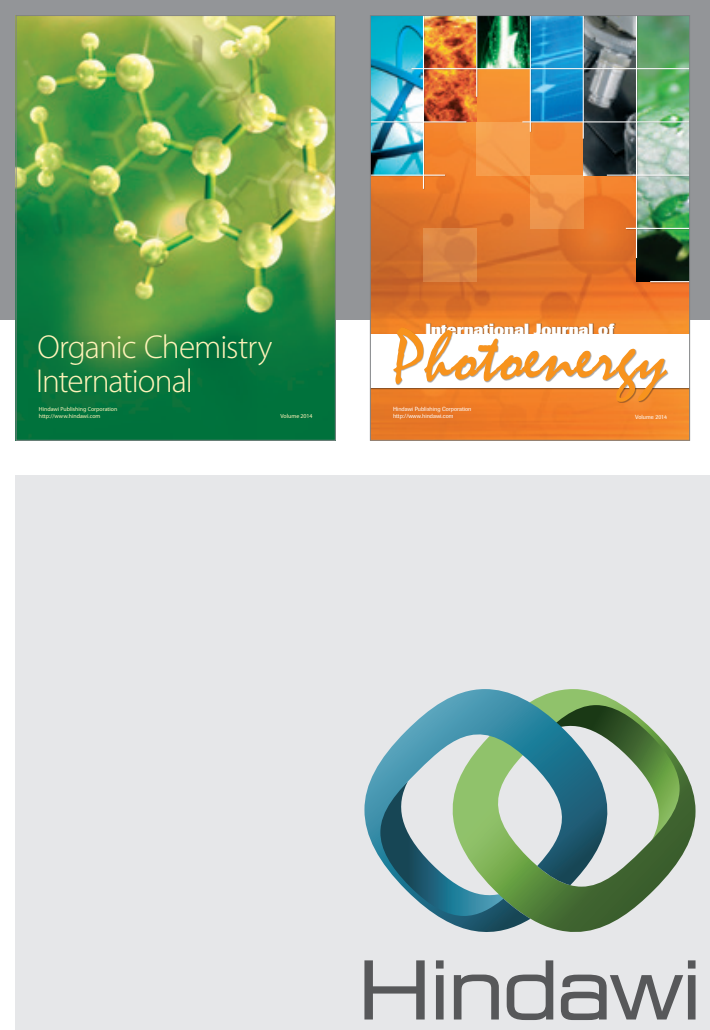

Submit your manuscripts at

http://www.hindawi.com
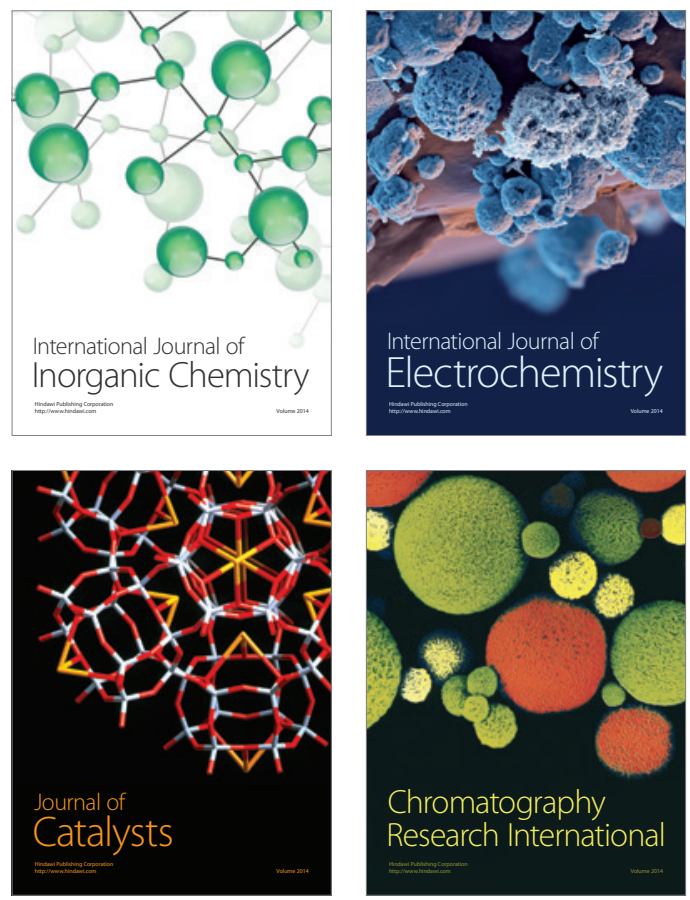
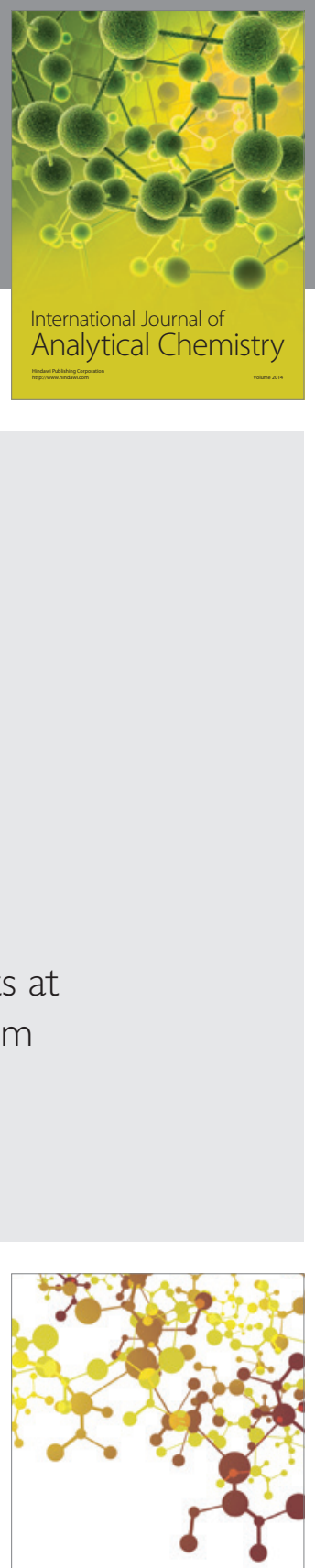

Journal of

Applied Chemistry
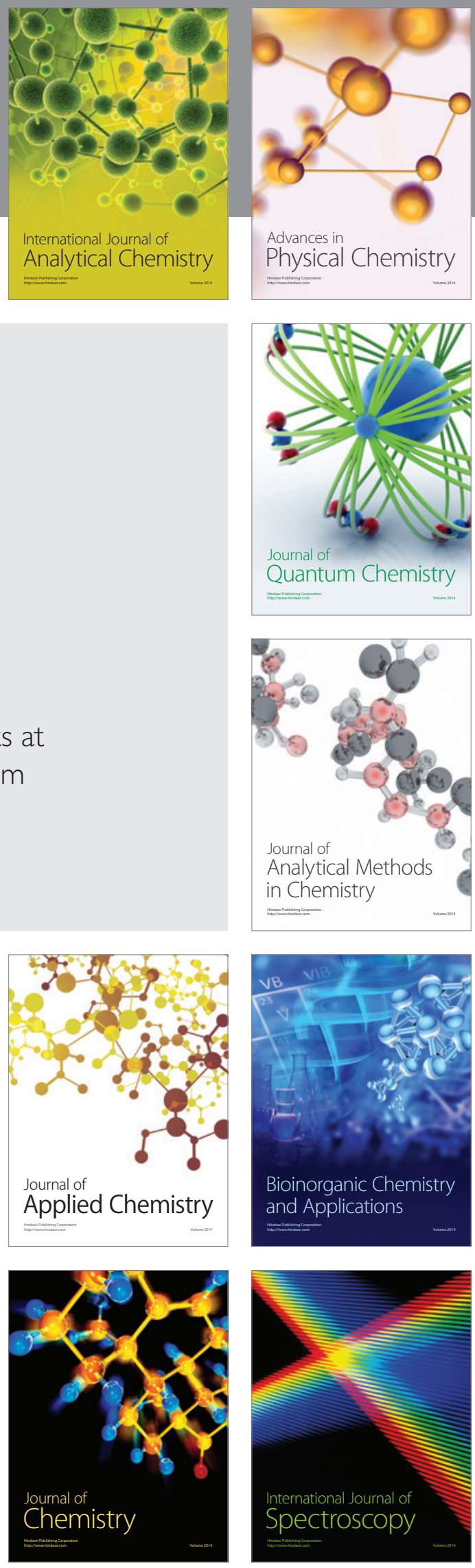